\title{
Interpretasi Dinamika Dan Warna Suara Pada Suite Populaire Bresilienne No. 1 Karya Villa Lobos
}

\author{
Mardian Bagus Prakosa \\ Institut Seni Indonesia Yogyakarta, Yogyakarta, Indonesia \\ Email: mardian.bagus.prakosa@isi.ac.id
}

\begin{abstract}
This research was conducted in order to formulate the interpretation of dynamics and timbre in Suite Populaire Brésilienne No.1 by Heitor Villa-Lobos. Based on the results of the pre-study, this work is one of the classical guitar's works that has many repetitions, so that efforts to avoid the impression of monotony need to be done. The purpose of this study is to identify the structure and musical form, determine the relationship between musical structures, and interpret them through dynamics and timbre. This study uses a qualitative research type with a musicological approach. Data collection techniques were carried out by observation, interviews, and documentation studies. The results showed that Mazurka-Choro is a suite with the ABACA rondo form in which each period has a repetition. The interpretation of dynamics and timbre is generally formulated through the tonality of each period by taking into account the tempo and rhythmic patterns. Furthermore, that a general description of the dynamics and timbre through consideration of tonality, tempo, and rhythm must be complemented by an understanding of the structure of motifs and harmony. The dynamics of the melodic structure are not only interpreted according to the direction of the melodic line, but can also be interpreted the other way around based on harmony or consideration of conceptual relations between structures or concepts that are determined in order to provide a differentiator for repetition of sentences.
\end{abstract}

Keywords: interpretation, dynamics, sound color, classical guitar, Villa Lobos

Abstrak: Penelitian ini dilakukan dalam rangka memformulasikan interpretasi dinamika dan warna suara pada Suite Populaire Brésilienne No.1 karya Heitor Villa-Lobos. Berdasarkan dari hasil observasi pra penelitian, karya tersebut merupakan salah satu karya gitar klasik yang memiliki banyak pengulangan kalimat, sehingga upaya untuk menghindari kesan monotone perlu dilakukan. Tujuan dari penelitian ini adalah mengidentifikasi struktur dan bentuk musik, mengidentifikasi hubungan antar struktur musik, dan menginterpretasikannya melalui pengelolaan dinamika dan warna suara. Penelitian ini menggunakan jenis penelitian kualitatif dengan pendekatan musikologis. Teknik pengumpulan data dilakukan dengan observasi, wawancara, dan studi dokumentasi. Hasil penelitian menunjukan bahwa Mazurka-Choro merupakan suita dengan bentuk rondo ABACA yang setiap kalimatnya memiliki pengulangan. Interpretasi dinamika dan warna suara secara umum diformulasikan melalui tonalitas dengan mempertimbangkan tempo dan pola ritmis. Lebih dalam lagi, bahwa gambaran umum tentang dinamika dan warna suara melalui pertimbangan tonalitas, tempo, dan ritme harus dilengkapi dengan pemahaman struktur motif dan harmoni. Dinamika pada struktur melodi tidak hanya diinterpretasikan sesuai dengan arah dari perjalanan melodinya namun, dapat juga dapat diinterpretasikan sebaliknya berdasarkan harmoni ataupun pertimbangan relasi konsep antar struktur ataupun konsep yang ditentukan dalam rangka memberikan pembeda pada pengulangan kalimat.

Kata Kunci: interpretasi, dinamika, warna suara, gitar klasik, Villa Lobos

\section{Article info:}

Received: 03 November 2021

Reviewed: 18 November 2021

Accepted: 29 November 2021

\section{PENDAHULUAN}

Kurikulum gitar klasik baik dalam lembaga pendidikan formal ataupun informal didesain untuk memastikan keseimbangan aspek fisikal, mental, musikal, dan aural pada siswa. Perlu diketahui bahwa pembelajaran gitar klasik tidak hanya menekankan pada keterampilam teknik memainkan instrumen (aspek fisikal) saja. Melalui proses pembelajaran, siswa juga dituntut untuk dapat meningkatkan aspek mental, musikal, dan aural seiring dengan peningkatan kualitas teknik, sehingga dalam tahap tertentu diharapkan dapat memiliki pemahaman musik yang mendalam. Pemahaman musik terbentuk melalui proses pencarian sadar atas bagaimana mengungkapkan musik dengan 
tepat, dinamika yang tepat, dan tempo yang tepat (Scruton, 2016). Proses inilah yang nantinya akan menjadi landasan siswa dalam pembentukan karakter yang mempengaruhi gaya bermain dalam pertunjukan. Pemahaman akan berkembang menjadi pemaknaan dan pemaknaan inilah yang melahirkan keunikan dari setiap musisi.

Salah satu sumber keunikan musisi berasal dari interpretasikan teks musik (aspek musikal dan aural) dan bagaimana merealisasikannya melalui permainan (aspek fisikal dan mental). Interpretasi musik direalisasikan melalui parameter ekspresi seperti timing, dinamika, artikulasi, dan warna suara (Reid, 2002). Instruksi yang tertera pada teks musik pada dasarnya bersifat lentur. Personal interpretation adalah keistimewaan yang diberikan oleh komposer kepada pemain dan keistimewaan tersebut harus dapat dipertanggung jawabkan (Godlovitch, 2002). Musisi memiliki keleluasaan untuk menentukan bagaimana nada akan dimainkan, misalnya, sejauh mana vibrasi dapat dilakukan pada karyakarya periode barok, menentukan warna suara dan dinamika untuk menciptakan kontras pada karya-karya periode klasik, dll. Keleluasaan yang dimaksud bukan berarti tanpa batasan atau manasuka. Oleh karena itu, peran pengajar sangat dibutuhkan dalam mendampingi dan memberikan penjelasan kepada siswa tentang kemungkinan- kemungkinan dan batasanbatasan interpretasi sehingga keleluasaan ini tidak menjadi manasuka. Terlebih, di era digital ini, karya- karya musik dari platform digital sering menjadi landasan siswa dalam menginterpretasikan karya musik. Dampak positif yang dihasilkan adalah kekayaan referensi tentang interpretasi musik. Namun, dampak negatifnya adalah siswa berusaha melakukan imitasi melalui audio tanpa memahami teks musiknya atau mencoba memahami latar belakang konsep interpretasi tersebut, sehingga kejanggalan interpretasi sering terjadi.

Pengajar memiliki peran dalam memberikan alternatif interpretasi sehingga siswa dapat melihat kemungkinan dan menentukan bagaimana sebuah karya musik akan dimainkan. Tentu, memberikan dan menyajikan alternatif interpretasi harus disertai dengan argumentasi yang kuat dengan mempertimbangkan hal-hal yang bersifat musikal, seperti alur melodi, progresi harmoni, relasi antar kalimat, dll melalui analisa struktur teks musik dan non-musikal, seperti mood dan visualisasi terhadap objek tertentu melalui pendalaman literatur. Oleh karena itu, penelitian yang berkaitan dengan interpretasi perlu dilakukan dengan tujuan meningkatkan kemampuan siswa dalam menginterpretasikan musik, khususnya gitar klasik.

Penelitian ini membahas tentang interpretasi pada Suite Populaire Brésilienne no. 1 Karya Heitor Villa-Lobos, fokus pada interpretasi dinamika dan warna suara. Interpretasi dilakukan berlandaskan 7 (tujuh) poin penting tentang interpretasi yang dikemukakan oleh Gerald Klickstein melalui buku berjudul The Musician's Way: A Guide to Practice, Performance, and Wellnes, terutama pada point yang membahas tentang dinamika dan warna suara. Istilah "fisik" dari warna suara yang digunakan dalam penelitian ini merujuk pada klasifikasi warna suara pada gitar klasik yang dikemukakan oleh Caroline Traube melalui penelitiannya yang berjudul An Interdisciplinary Study of the Timbre of the Classical Guitar.

Hasil observasi pra penelitian menunjukan bahwa karya tersebut merupakan salah satu karya gitar klasik yang memiliki banyak pengulangan kalimat. Penulis melihat bahwa repertoar ini dapat dianalogikan seperti kerangka sebuah rumah dalam lukisan yang memiliki bentuk namun belum memiliki warna. Hal ini dapat dibuktikan dengan terbatasnya tanda-tanda ekspresi pada teks musik Suite Populaire Brésilienne No. 1. Berangkat dari permaslahan tersebut, merumuskan formulasi interpretasi dinamika dan warna suara yang dilengkapi dengan petunjuk teknis tentang bagaimana merealisasikannya melalui teknik permainan gitar menjadi sangat penting, sehingga penelitian ini bisa menjadi media pembelajaran aplikatif tentang pengelolaan dinamika dan warna suara sebagai upaya menghindari kesan monotone. Selain itu, proses formulasi interpretasi terhadap teks musik ini dapat diaplikasikan pada karya-karya musik secara luas sehingga diharapkan dapat menambah cakrawala pengetahuan khususnya tentang interpretasi dinamika dan warna suara.

\section{METODE}

Penelitian ini menggunakan jenis penelitian kualitatif dengan pendekatan musikologis. Pendekatan musikologis 
digunakan untuk menganalisa teks musik dan mengidentifikasi hubungan antar struktur. Subjek dalam penelitian ini adalah teks musik dari Suite Populaire Bresilienne edisi eschig. Struktur-struktur yang teridentifikasi diinterpretasikan melalui parameter ekspresi yang berhubungan dengan dinamika dan warna suara. Interpretasi dinamika dan warna suara tersebut dideskripsikan secara instruksional karena proses realisasi interpretasi bersinggungan dengan aspek teknis.

Teknik pengumpulan data dilakukan dengan observasi, wawancara, dan studi dokumentasi (Rukajat, 2018). Penulis menggunakan nonprobability sampling dengan teknik purposive sampling (Sugiyono, 2013). Penelitian ini dilakukan dalam upaya menginterpretasikan dinamika dan warna suara pada jenis karya yang memiliki banyak pengulangan di dalamnya. Oleh karena itu, kriteria sampel dalam penelitian ini adalah struktur musik yang dikembangkan melalui repetisi. Data yang diperoleh dari kriteria sampel ini selanjutnya diberikan perlakuan dengan mempertimbangkan relasi dari struktur yang terkecil hingga keseluruhan.

Analisis data dilakukan menggunakan analisa bentuk dan struktur musik yang telah dikembangkan oleh Karl-Edmund Prier pada tahun 1996. Secara teknis, repertoar akan diurakan dari struktur musik yang terkecil hingga struktur musik yang terbesar (Prier, 2017). Struktur-struktur ini diidentifikasi dan diklasifikasikan sehingga penulis dapat melihat gambaran karya secara umum. Selanjutnya, hasil identifikasi dan klasifikasi musik diinterpretasikan berdasarkan tonalitas, tempo, ritmis, struktur melodi, dan harmoni berlandaskan pada gagasan Gerald Klickstein. Interpretasi dinamika ditentukan oleh melodic line dengan mempertimbangkan harmoni. Selain itu, terkait dengan dinamika, penulis berorientasi pada pengelolaan dinamika dalam rangka mengindari kesan monotone, sehingga alternatif lain dari interpretasi dinamika dapat direalisasikan pada putaran kedua pada repetisi sebagai upaya memberikan perbedaan pada struktur musik yang sama. Interpretasi warna suara berlandaskan pada hasil asosiasi antara tonalitas dan warna oleh Elena Anisimova dan dijabarkan melalui jenis-jenis warna suara pada gitar klasik yang diklasifikasikan oleh Caroline Traube, sehingga melalui dua landasan tersebut penulis dapat menjabarkan melalui bentuk "fisik" warna suara. Hal ini dilakukan untuk mempermudah pembaca dalam memahami penelitian ini.

Selain itu, penulis menggunakan konsep analisis data Miles dan Huberman. Berdasarkan konsep analisis data tersebut, terdapat beberapa komponen, yaitu: (1) pemilahan hal-hal pokok dari banyaknya data yang diperoleh dari lapanan (reduksi data); (2) Hasil reduksi disajikan secara deskriptif dan dilengkapi dengan gambargambar pendukung (penyajian data; dan (3) Penarikan kesimpulan (Miles Matthew B. \& Hubermann A. Michael, 1994).

Validitas data diperlukan untuk setiap jenis penelitian dalam menguji keabsahan. Teknik peer de briefing akan digunakan untuk memeriksa keabsahan data dengan melakukan tanya jawab dengan sesama peneliti atau akademisi musik yang expert dalam instrumen gitar. Mendapatkan interpretasi lain di luar interpretasi penulis dapat menambah validitas dari hasil penelitian (Creswell, 2012).

\section{HASIL DAN PEMBAHASAN \\ Hasil}

Suite Populaire Bresilenne dibuat secara eksklusif dari potongan choro: Mazurka- Chôro, Schottish Chôro, Valsa-Chôro, Gavotta-Chôro dan Chôrinho. Lima bagian suite ini dibuat antara tahun 1906-1923. Mazurka-Chôro adalah bagian awal dari rangkaian suita, didedikasikan untuk Maria Tereza Teran, istri dari teman baik Villa Lobos. Hampir semua bagian memiliki bentuk rondo kecuali potongan terakhir, Chôrinho. Genre Choro populer di Brazil pada tahun 1870 dan 1920. Menurut Marcelo Mello, choro dianggap sebagai perpaduan La Modhina (lagu sentimental dari Portugis dan diiringi gitar) dan lundu (lagu dan tarian asal angola yang dibawa ke Brazil) (Grajales Hernández, 2010). Selain itu terdapat juga pengaruh dari musik eropa seperti waltz, mazurka, polka, dll. Choro dikatakan sebagai musik yang memiliki harmonisasi eropa dengan cita rasa brazil.

Penelitian tentang interpretasi dinamika dan warna suara pada Suite Populaire Bresilienne No. 1 Mazurka-Choro dilakukan setelah melakukan observasi. Hasil observasi menunjukan bahwa karya tersebut dibangun dengan bentuk rondo ABACA+Coda dan setiap kalimatnya dikembangkan melalui pengulangan. Dinamika dan warna suara pada Mazurka-Choro secara umum diinterpretasikan melalui struktur tonalitas, instruksi tempo, dan pola ritme yang disediakan dalam teks musik. Melalui ketiga 
aspek tersebut gambaran tentang konstruksi dasar dinamika dan warna suara dapat dirumuskan. Pada karya ini, kalimat utama A merupakan pusat dari kalimat B dan C. Resolusi insitas dinamika selalu meningkat pada setiap kalimat melalui tonalitas minor (A), mayor (B), dan paralel dari A (C).

Secara khusus, dinamika utama pada kalimat A adalah mezzoforte dengan warna suara nasal dan round melalui posisi flautando. Dinamika mezzoforte tersebut berkembang sesuai dengan alur melodi dan harmoni yang teridentifikasi. Pada putaran kedua tingkat kecerahan pada warna suara sedikit naik melalui posisi sul tasto. Kalimat B diinterpretasikan dengan forte, thick, dan bright berdasarkan tonalitasnya. Untuk merealisasikannya dinamika dan khsusnya warna suaranya, penulis memilih posisi tangan kanan center position. Selain tebal, warna suara terang dapat terbentuk melalui posisi tersebut. Konsep pengelolaan dinamika pada putaran pertama direalisasikan dengan statis, tanpa adanya perubahan dinamika yang signifikan kecuali pemberian sedikit penekanan pada kemunculan akor E mayor. Namun dalam pengulangan, pengelolaan dinamika dan warna suara dilakukan dengan lebih dinamis, menempatkan dinamika piano dan crescendo pada setiap awal anak kalimat. Hal itu dilakukan dalam rangka menghindari kesan monotone dan dalam upaya untuk memperkaya ekspresi musikal pada kalimat B.

Kalimat C pada dasarnya diinterpretasikan dengan cara yang sama berdasarkan tonalitas dan alur melodi. Namun perlu dipahami bahwa, kalimat $\mathrm{C}$ merupakan puncak dari semua kalimat. Oleh karena itu, Dinamika forte dan warna suara thick dan bright dirasa cocok untuk merepresentasikan kalimat ini. Realisasinya dilakukan melalui pemilihan posisi center position dan fokus untuk mengasilkan sound yang lebih tebal dan cerah dibandingkan dengan kalimat B. Tanda-tanda ekspresi pada teks musik jauh lebih beragam dibandingkan dengan kalimat-kalimat sebelumnya, sehingga tidak diperlukan perbedaan konsep interpretasi pada pengulangan.

Koda memiliki tonalitas yang cukup kabur, sehingga penulis menginterpretasikan dengan melihat keseluruhan konsep interpretasi kalimat-kalimat sebelumnya dan diperoleh bahwa interpretasi penulis menyimpang dari instruksi dinamika pada teks musik. Pengulangan motif direalisasikan melalui kontras dinamika, diawali dengan piano dan motif berikutnya dengan forte. Perjalanan menuju cadence yang memiliki fungsi tambahan sebagai klimaks direalisasikan melalui crescendo dari dinamika piano menuju forte dan diakhiri dengan fortissimo.

\section{Pembahasan}

Stan Godlovitch berfikir bahwa musisi memiliki privilege berupa kebebasan yang bertanggung jawab dalam menginterpretasikan teks musik (Godlovitch, 2002). Penulis meyakini bahwa interpretasi dapat dipertanggung jawabkan melalui pemahaman dan argumentasi terhadap hubungan antar struktur musik (intramusikal) dan hubungan antara musik dengan hal-hal di luar musik (ekstramusikal). Terkait dengan dinamika dan warna suara, interpretasi memuat fluktuasi emosional dan salah satu cara dalam mengkomunikasikan perubahan intensitas adalah dengan merubah volume (shape dynamics (Klickstein, 2009). Secara umum volume dapat ditentukan melalui garis melodi (melodi naik-volume naik). Namun, intensitas musik tidak hanya ditentukan oleh alur melodi saja, musisi juga harus mempertimbangkan progresi harmoninya. Sedangkan warna suara dimaknai sebagai pendukung dari rumusan dinamika.

Fungsi dari perubahan warna suara pada umumnya dilakukan untuk memaknai struktur tertentu dan mengimitasi objek lain di luar musik. Namun, perlu disadari bahwa dalam memberikan instruksi warna suara, definisi fitur warna suara berkaitan dengan aspek "fisik" suara. Oleh karena itu dalam mendeskripsikan warna suara, penulis merujuk pada penelitian yang berhubungan dengan warna suara pada gitar klasik. Caroline Traube merangkum 10 kata sifat yang sering digunakan oleh musisi profesional dalam mendefinisikan atau menginstruksikan warna suara, seperti: $d r y$, nasal, thin, metallic, bright, round, warm, thick, velvety, dan dark (Traube, 2004). Dalam penelitian ini, kata sifat tersebut digunakan sebagai gambaran imajinatif dan dilengkapi dengan petunjuk teknis, seperti: flautando, sul tasto, normale, dan sul ponticello yang merujuk pada range posisi tangan kanan yang berorientasi pada variasi warna suara itu sendiri. Oleh karena itu, terkait dengan upaya pertanggung jawaban interpretasi, pembahasan pada penelitian ini 
berisi penjabaran tentang latar belakang karya, analisa bentuk dan struktur, serta interpretasikan dinamika dan warna suara berdasarkan bentuk dan struktur musik.

Mazurka-Choro merupakan suita pertama dalam suite popolaire bresilienne yang memiliki bentuk rondo lima bagian dan memiliki coda (gambar 1). Lima bagian tersebut terdiri dari tema utama (A), episode 1 (B), dan episode 2 (C), dengan urutan ABACA

+ Coda. Merujuk pada partitur edisi ESCHIG, setiap bagian memiliki tanda repetisi, sehingga urutan dalam memainkannya adalah AABBAACCAA + Coda. Tema utama (A) dalam A minor terdiri dari 2 (dua) motif pada kalimat tanya dan 2 (dua) motif pada kalimat jawab. Tempo pada bagian ini menunjukan tempo lambat atau dalam teks tertulis $\mathrm{Un} \mathrm{Peu}$ Lent. Motif pada episode pertama (B) juga memiliki jumlah yang sama dan terbagi dalam kalimat tanya dan jawab dengan tempo lambat, dimulai dari akrod $\mathrm{V}$ dari $\mathrm{C}$ major atau akor VII dari A minor dan diakhiri dengan $\mathrm{C}$ mayor. Pada Episode kedua terdapat peningkatan kuantitas motif sehingga kalimat tanya dan jawab masingmasing memiliki 8 (delapan) birama dalam A mayor. Pada bagian akhir, koda pada dasarnya memiliki tonalitas yang lemah karena dibangun dengan broken chord yang merujuk pada akor tiga belas, sebagian memiliki third dan sebagian tidak. Namun setelah melihat keseluruhan bagian koda, dapat disimpulkan bahwa tonalitas pada koda adalah A minor.

Bentuk Rondo 5 (lima) Bagian + Coda Mazurka-Choro

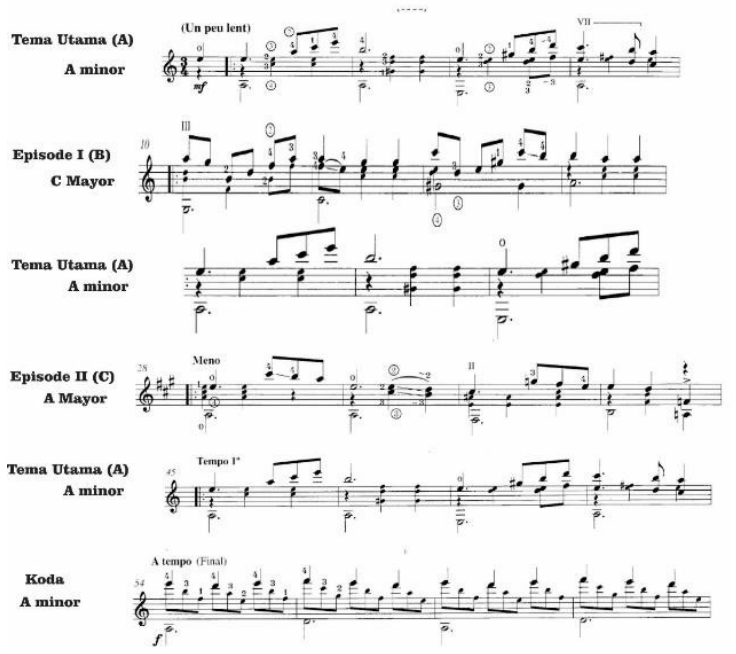

Gambar 1. Bentuk rondo dan tonalitas
Berbeda dengan waltz, mazurka memiliki aksen pada ketukan kedua. Pengetahuan tentang karakteristik ketukan ini memiliki implikasi pada pengelolaan dinamika pada kelompok motif. Interpretasi dinamika dan warna suara secara umum dapat dirumuskan melalui sudut pandang tonalitas pada setiap bagian, dimana bagian A sebagai sentral dari bagian $\mathrm{B}$ dan $\mathrm{C}$ (gambar 2). Bagian B dengan tonalitas $\mathrm{C}$ mayor dapat diinterpretasikan lebih "cerah" daripada bagian A dalam A minor. Bagian $\mathrm{C}$ dalam A mayor menjadi kontras dari bagian-bagian yang lain dan dapat dijadikan sebagai tahapan akhir dari gagasan komposer. Oleh karena itu bagian $\mathrm{C}$ diinterpretasikan dengan bagian yang paling "cerah" dan dan diaksentuasikan dengan tempo yang lebih lambat atau dalam teks digunakan istilah meno. Koda dapat dimaknai dengan klimaks sehingga pengelolaan resolusi dinamika dan warna suara dapat memperhatikan alur melodi dan progresi sehingga pada birama akhir dapat memperdengarkan Fortissmo pada interval octave dan akord A minor.

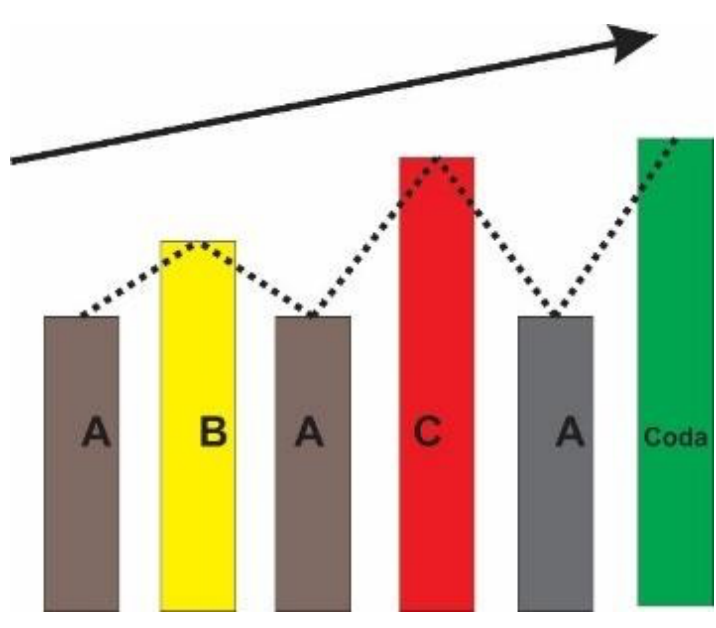

Gambar 2. Intensitas dinamika mazurka-choro

Pada tema utama (A), interpretasi dinamika dapat direalisasikan berdasarkan pergerakan melodi dan harmoni yang diawali dengan dinamika mezzoforte (gambar 3 dan 4). Pemain harus memahami penekanan pada ketukan kedua, memberikan kesan cukup ringan pada melodi yang berada diketukan pertama dan kesan ringan pada ketukan ketiga. Upaya untuk menghindari kesan monotone dapat dilakukan melalui interpretasi warna suara. Interpretasi warna suara pada putaran pertama direalisasikan melalui warna suara nasal dan round pada putaran kedua. Penulis mempertimbangkan variasi warna suara tersebut berdasarkan aspek 
tonalitas. Menurut Elena Nikolaevna Anisimova (Anisimova, 2015), tonalitas minor diasosiasikan dengan istilah dingin, natural, dan warna pasif dengan sedikit pencahayaan. Oleh karena itu pemilihan variasi warna suara nasal dan round dapat merepresentasikan tonalitas minor. Secara teknis, putaran pertama dapat dilakukan melalui posisi flautando dan putaran kedua melalui posisi sul tasto.

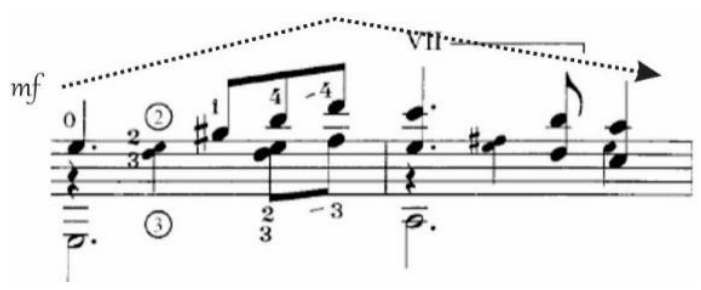

Gambar 3. Dynamics line birama 1 dan 2

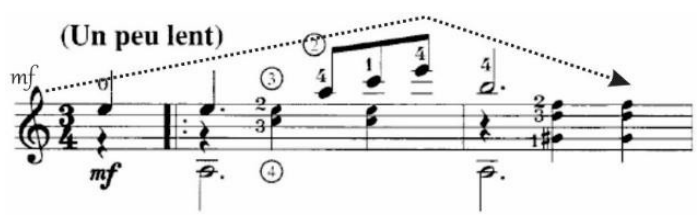

Gambar 4. Dynamics line birama 3 dan 4.

Selain berorientasi pada keindahan suara, vibrasi dapat dilakukan sebagai upaya mendukung dinamika dan warna suara. Vibrasi dapat digunakan pada nada-nada panjang, seperti nada B, C, F pada birama 2, 4, dan 6. Tidak hanya itu, vibrasi juga dapat direalisasikan untuk mendukung ritmis choro dimana tekanan ada pada ketukan kedua. Namun realisasi ini harus dikelola dengan baik sehingga terhindar dari kesan monotone. Penulis memilih merealisasikan vibrasi iringan ketukan kedua pada birama 2 dan 6 .

Pada episode pertama (B), interpretasi dinamika dan warna suara terbagi menjadi dua, yaitu interpretasi putaran pertama dan kedua. Putaran pertama birama 10-17 dimulai dengan dinamika forte dengan warna suara thick atau tebal. Perlu diperhatikan bahwa kehadiran kalimat baru harus benar-benar disadari oleh musisi. Kesadaran ini akan mempengaruhi ekspresi musikal atau minimal melalui kesadaran ini musisi dihadapkan pada opsi-opsi interpretasi tentang bagaimana merealisasikan kalimat baru sehingga memiliki makna musikal. Episode pertama ini memiliki tonalitas mayor. Menurut penulis, komposer menciptakan sebuah perjalanan yang awalnya terkesan dingin, natural, dan sedikit pencahayaan (tonalitas minor) berubah menjadi aktif, terang, bersinar, dan hangat (tonalitas mayor) (Anisimova, 2015). Oleh karena itu, pemilihan warna suara yang "tebal" dirasa cocok untuk merepresentasikan kalimat baru (B). Warna suara thick dapat diperoleh melalui dinamika forte dan posisi tangan kanan berada di center position. Tidak hanya menghasilkan warna suara yang tebal, namun pemilihan center position juga menghasilkan warna suara yang cerah.

Selain tonalitas, harmoni juga merupakan aspek yang mempengaruhi pemilihan dinamika dan warna suara. Pada birama 12 ditemukan perjalanan akor yang tidak terduga, yaitu perjalanan dari $\mathrm{G}$ mayor pada birama 10, C mayor pada birama 11, dan E mayor. Tidak hanya harmoni, pergerakan melodi pada kalimat tanya B juga menunjukan bahwa nada tertinggi berada pada birama 12. Pada birama ini dapat diberikan penekanan dengan menaikan level dinamika dan penekanan warna suara melalui vibrasi. Namun perlu dipahami bahwa putaran pertama dan kedua diinterpretasikan dengan cara yang berbeda. Oleh karena itu, pada putaran pertama intesitas dinamika dan warna suara dimainkan dengan cukup statis.

Pada putaran kedua, konsep crescendo dapat diterapkan dengan memulai birama 10 dengan dinamika piano, peningkatan dinamika selanjutnya pada birama 12 , kembali ke piano pada birama 14, dan secara bertahap naik atau crescendo dan diakhiri dengan forte. Hal ini dilakukan untuk menunjukan "kekayaan" musisi ketika dihadapkan dengan kalimat yang berulang. Interpretasi pada putaran kedua berhubungan dengan upaya membangun kontras dengan putaran pertama dan membangun kontras pada saat kembali ke tema utama A. Tema utama diinterpretasikan sama persis seperti sebelumnya, sehingga saat kembali ke tema utama akan memberikan kesan bahwa tema utama merupakan poros. Hal ini dilakukan untuk memperkuat makna dari bentuk musik rondo.

Episode 2 (C) merupakan paralel dari tema utama dimana tema utama memiliki tonalitas minor dan episode 2 memiliki tonalitas mayor dalam tangga nada A. Instruksi tempo yang tertera adalah meno atau merujuk pada tempo yang sedikit lebih lambat dari tempo sebelumnya un peu lent. Instruksi-instruksi yang teridentifikasi, seperti: rallentando, aksen, a 
tempo, dan fermata menunjukkan bahwa komposer menginginkan episode 2 dimainkan lebih ekspresif dibandingkan dengan tema utama dan episode 1. Melalui sudut pandang struktur melodi, gagasan utama yang diperkembangkan adalah sekuen turun.

Kolaborasi antara tonalitas mayor dan tempo lambat menghasilkan karakter musik yang romantis dan melodis (Anisimova, 2015). Interpretasi secara umum tentang dinamika dan warna suara dapat berlandaskan pada tonalitas dan dapat direalisasikan dengan dinamika forte dan warna suara bright dan thick. Warna suara bright dapat diperoleh melalui center position dan dinamika forte. Center position juga cenderung menghasilkan sound yang tebal dan ketebalan tersebut dapat tingkatkan melalui vibrasi. Secara khusus, pengelolaan dinamika dan warna suara merujuk pada alur melodi dan harmoni. Pada birama 28 puncak not tertinggi adalah $\mathrm{C}$ yang terkesan memberi ketegangan yang kemudian release secara bertahap melalui nada $\mathrm{B}, \mathrm{A}$, dan $\mathrm{E}$. Tension dan release ini dapat dikelola dengan pengelolaan dinamika sesuai dengan alur melodi. Namun perlu diingat bahwa pemberian aksen dalam rangka meningkatkan ketegangan melalui dinamika harus dihindari, mengingat nada tertinggi berada pada up beat. Birama 28 dan 29 menujukkan adanya penurunan ketegangan dari sudut pandang melodi dan harmoni. Selanjutnya, tension dan release muncul kembali pada akor $\mathrm{F}$ ke $\mathrm{E}$ mayor, dilanjutkan dengan sekuen turun pada birama 32, 33, dan 34. Sekuen turun diawali dengan nada D, $B$, dan $G$, sehingga dinamika dapat diinterpretasikan turun mengikuti alur melodi. Dinamika yang turun secara bertahap ini dapat didukung dengan menurunkan "ketebalan" warna suara. Pada birama 34 penekanan melodi dapat dilakukan mengikuti instruksi yang ada pada teks musik. Cara untuk menemukan rallentando yang tepat adalah dengan menyanyikan dan opsi pengelolaan vibrasi juga dapat dilakukan terutama pada nada G. Pemilihan dinamika dan warna suara pada birama 35 hendaknya mempertimbangkan birama sebelum dan sesudahnya. Nada D\# merupakan rangkaian melodi dari motif sebelumnya, namun pada nada $\mathrm{C} \#$ atau akor $\mathrm{A}$ mayor pada ketukan terakhir birama 35 secara fungsional merupakan masa transisi dari rallentando ke a tempo dan dari akhir kalimat menuju awal kalimat. Oleh karena itu pada akor A minor perlu adanya dukungan dinamika dan warna suara yang sedikit lebih keras dan tebal disesuaikan dengan birama 36. Upaya memperhalus dapat dilakukan pada birama 35 ketukan pertama dilakukan melalui dinamika piano dan crescendo, sehingga kesatuan antar kalimat dapat terbangun.

Pengelolaan dinamika pada birama 36 -39 dapat disamakan dengan birama 28 berdasarkan persamaan melodi dan harmoni. Namun dalam rangkaian akhir birama 40, ritardando dapat didukung dengan vibrasi terutama pada melodi $\mathrm{G}$, sehingga vibrasi dapat dijadikan media untuk menurunkan kecepatan. Vibrasi juga dilakukan pada fermata pada ketukan terakhir pada birama 42. Pada konteks ini, fermata dapat mengkonversi not $1 / 8$ menjadi $1 / 4$ atau $1 / 2$. Hal ini dilakukan sebagai penanda berakhirnya kalimat. Konsep pengelolaan dinamika dan warna suara pada episode 2 ini berbeda dengan tema utama dan episode 1 dalam pengelolaan pengulangan. Episode 2 memiliki kekayaan motif dan tanda-tanda ekspresi sehingga pengulangan pertama dan kedua dapat dilakukan dengan cara yang sama.

Pada koda minimnya penggunaan third menjadikan tonaltas terasa kabur. Tonalitas yang kabur mempengaruhi keputusan dalam proses pengelolaan dinamika. Namun, teks musik memberikan instruksi bahwa koda dimulai dengan dinamika forte dan tidak ada lagi instruksi dinamika sampai birama 61 . Berdasarkan hasil analisa penulis, birama 56 dan 57 merupakan pengulangan identik dari birama 54. Selanjutnya, pada birama 58 sampai 63 ketukan pertama merupakan rangkaian sekuen turun, dimana birama 62 teks musik menginstruksikan untuk bermain dalam dinamika mezzoforte, crescendo, dan dibalut dengan rallentando. Instruksi tersebut dimaknai sebagai proses persiapan menuju cadence. Ditutup dengan rangkaian sekuen naik dan turun, kemudian diakhiri dengan octave dan akor A minor dalam dinamika Fortissimo.

Dari hasil analisa struktur musik tersebut, penulis menginterpretasikan dinamika tidak sesuai dengan instruksi pada teks. Kemungkinan tersebut dapat dilakukan khususnya untuk karyakarya musik pada abad ke-20, dimana dalam interpretasi, pemain dapat menekankan sifat radikalnya (Rosen, 2017). Birama 54 dan 55 dimainkan dengan dinamika piano. Warna suara yang sesuai adalah thin dan warm, direalisasikan melalui tasto. Selanjutnya, kontras dilakukan melalui dinamika forte dan menggunakan warna 
suara thick dan bright melalui center position pada birama 56 dan 57. Pada birama 58-62, sekuen turun diinterpretasikan berbanding terbalik dengan dinamika. Dimulai dengan dinamika piano-crescendo dan cadence pada birama 63 menggunakan dinamika forte. Rangkaian penutup sekuen naik dan turun bertahan pada dinamika forte dengan warna suara bright dan diakhiri dengan octave dan akor A minor menggunakan dinamika fortissimo dengan warna suara bright dan thick.

Pada koda, penulis menginterpretasikan pengulangan motif dengan dinamika dan warna suara yang berbeda. Instruksi forte digantikan dengan piano dengan asumsi bahwa pada rangkaian sekuen turun pada birama 58 dapat diawali menggunakan piano-crescendo, dan bermuara pada cadence birama 63 sehingga cadence akan menjadi klimaks sementara. Gitar klasik bukanlah instrumen yang memiliki rang dinamika yang luas seperti instrumen piano, gesek, atau tiup logam. Pencapaian klimaks dapat dirasakan jika dimulai dengan dinamika lembut naik secara bertahap dan diakhiri dengan dinamika keras dengan warna suara yang tebal.

\section{KESIMPULAN}

Penelitian tentang Interpretasi dinamika dan warna suara pada Suite Populaire Bresilienne No. 1 Mazurka - Choro karya Villa Lobos merupakan upaya untuk menghindari kesan monotone pada jenis karya yang dibangun dengan banyak pengulangan. Mazurka-Choro merupakan suita dengan bentuk rondo ABACA yang setiap kalimatnya memiliki pengulangan. Interpretasi dinamika dan warna suara secara umum diformulasikan melalui tonalitas pada setiap kalimat dengan mempertimbangkan tempo dan pola ritmis. Lebih dalam lagi, bahwa gambaran umum tentang dinamika dan warna suara harus dilengkapi dengan pemahaman struktur motif dan harmoni. Sehingga, alur musik yang terbangun tidak menjadi statis dan monotone. Struktur melodi dapat diinterpretasikan sesuai dengan arah dari perjalanan melodinya. Namun, hal itu dapat diinterpretasikan sebaliknya berdasarkan harmoni ataupun pertimbangan relasi konsep antar struktur ataupun konsep yang ditentukan dalam rangka memberikan pembeda pada pengulangan kalimat seperti pada pengelolaan dinamika dan warna suara pada koda.

Interpretasi merupakan pusat dari aktifitas musik, sedangkan teknik adalah cara dalam merealisasikan interpretasi itu sendiri. Interpretasi pada penelitian ini berada pada tingkat interpretasi dasar dimana penulis hanya menginterpretasikan aspek material berupa teks musik berdasarkan tonalitas, tempo, alur melodi, harmoni, dan kesesuaian relasi antar struktur musik, dengan sedikit pengantar historis untuk mengungkap karakter ritmis pada mazurka.

\section{DAFTAR PUSTAKA}

Anisimova, E. N. (2015). The influence of major and minor tonality of music on an associative color-sound perception.

Creswell, J. W. (2012). Research Design: Pendekatan Kuantitatif, Kualitatif,dan Mixed (Edisi Ketiga). Pustaka Pelajar, 311.

Godlovitch, S. (2002). MUSICAL PERFORMANCE: A philosophical study.

Grajales Hernández, O. A. (2010). El choro y la suíte popular brasileira: reflejo de la tradición popular en Heitor Villa-Lobos.

Klickstein, G. (2009). The musician's way: A guide to practice, performance, and wellness. Oxford University Press.

Miles Matthew B. \& Hubermann A. Michael. (1994). Qualitative Data Analysis (Second Edi). Sage Publication.

Prier, K.-E. (2017). Ilmu Bentuk Musik (keenam). Pusat Musik Liturgi.

Reid, S. (2002). Preparing for performance. In Musical Performance (pp. 102-112). Cambridge University Press. https://doi.org/10.1017/CBO9780511811 739.008

Rosen, C. (2017). Freedom of interpretation in twentieth-century music. In CompositionPerformance-Reception (pp. 66-73). Routledge.

Rukajat, A. (2018). Pendekatan Penelitian Kualitatif(Qualitative Research Approach). Deepublish.

Scruton, R. (2016). Understanding music: Philosophy and interpretation. Bloomsbury Publishing.

Sugiyono. (2013). Metode Penelitian Kuantitatif, Kualitatif, dan R\&D. Alfabeta.

Traube, C. (2004). An Interdisciplinary Study of the Timbre of the Classical Guitar. (Issue October).

http://www.academia.edu/914878/An_inter disciplinary_study_of_the_timbre_of_the classical_guitar 